\title{
Armed On-board Protection of German Ships (and by German Companies)
}

\author{
Tim R. Salomon*
}

\begin{abstract}
Germany reacted to the rise of piracy around the Horn of Africa not only by deploying its armed forces to the region, but also by overhauling the legal regime concerning private security providers. It introduced a dedicated licensing scheme mandatory for German maritime security providers and maritime security providers wishing to offer their services on German-flagged vessels. This legal reform resulted in a licensing system with detailed standards for the internal organisation of a security company and the execution of maritime security services. Content wise, the German law borrows broadly from internationally accepted standards. Despite deficits in state oversight and compliance control, the licensing scheme sets a high standard e.g. by mandating that a security team must consist of a minimum of four security guards. The lacking success of the scheme suggested by the low number of companies still holding a license may be due to the fact that ship-owners have traditionally been reluctant to travel high-risk areas under the German flag. Nevertheless, the German law is an example of a national regulation that has had some impact on the industry at large.
\end{abstract}

Keywords: German maritime security, private armed security, privately contracted armed security personnel, anti-piracy-measures, state oversight

\section{Introduction}

It is seemingly a long time ago that piracy has risen and fallen around the Gulf of Aden. Discussing piracy today feels almost like it used to be, that is, discussing a historical topic. This of course is in stark contrast to the lively debate that took place five to ten years ago, when piracy was a public topic of most paramount interest. However, the comparative silence that surrounds piracy today is misleading to an extent. Piracy and maritime violence in general are still very much alive. While there has been a significant decrease of successful and attempted piratical attacks on trade vessels around the Horn of Africa, the phenomenon has shifted regionally, and, as

* The author is a legal adviser to the German Federal Armed Forces (Bundeswehr) and currently seconded to the German Federal Constitutional Court. The views and opinions expressed in this article and assumptions made therein are those of the author and do not necessarily reflect the official policy or position of any agency of the German government. The author wishes to thank the anonymous reviewers for their input. long as there will be wealthy nations and flourishing world trade, there will be maritime traffic and attempts of criminal gangs to benefit from it. ${ }^{1}$

Looking back to the high time of Somali piracy, Germany has reacted primarily by deploying its armed forces to the Horn of Africa as part of the EU Operation ATALANTA. ${ }^{2}$ The Federal Republic of Germany is a nation that has traditionally been very reluctant to deploy its military. Its constitution entails a restrictive framework reflecting the understanding that Germany, having learned from its dark history, is a nation of peace. ${ }^{3}$ It is a recent development that many Germans have come to terms with the fact that preserving and living up to this self-image in today's world means to act when atrocities happen and/or world peace is at peril. Accordingly, the armed forces are no longer restricted to territorial defence, but are increasingly understood as a means to counter crises internationally. ${ }^{4}$ This started with deployments in Cambodia and the Balkan region, both in $1992 .{ }^{5}$ The fight against piracy off the coast of Somalia has become a part of this development.

EU ATALANTA has had significant success. It met its primary objective, the protection of the World Food

1. For the development of piracy see the popular accounts of D. HellerRoazen, The Enemy of All (2009) and A. Konstam, Piracy (2008); for the rise of (relatively) more modern forms of piracy from 1500 to 1900 see M. Kempe, Fluch der Weltmeere (2010).

2. See the decision of the German government to participate in the EU-led operation ATALANTA, Bundestagsdrucksache (BT-Drs.) 16/11337, 10 December 2008 on the basis of the Security Council resolution regime starting with 1816 (2008) of 2 June 2008 and the EU Joint Action 2008/851/CFSP of 10 November 2008.

3. For an account hereof in the English language see R.A. Miller, 'Germany's Basic Law and the Use of Force', 17(2) Indiana Journal of Global Legal Studies 197, at 198 et seq. (Summer 2010).

4. See e.g. the speech of the Federal President, as he then was, Gauck on 31 January 2014 at the Munich Security Conference, accessible in English available at: http://www.bundespraesident.de/SharedDocs/ Downloads/DE/Reden/2014/01/140131-Muenchner-

Sicherheitskonferenz-Englisch.pdf. In the recent past, the willingness to deploy armed forces in ad hoc coalitions, e.g. to counter the threat posed by the so-called Islamic State, evidences this tendency; see e.g. Weißbuch 2016 zur Sicherheitspolitik und zur Zukunft der Bundeswehr, at 81, 108 et seq., available at: https://www.bmvg.de/de/ themen/weissbuch; Federal Ministry of Defence, 'Konzeption der Bundeswehr', 20 July 2018, at 6 and 25 https://www.bmvg.de/de/ aktuelles/konzeption-der-bundeswehr-26384. Prior to this step, deployments were limited almost exclusively to NATO operations or operations based on Security Council resolutions pursuant to Chapter VII of the UN Charter.

5. W. Link, Deutsche Außenpolitik (2006), at 197; H. Kundnani, German Power: Das Paradox der deutschen Stärke (2016), at 75; M. Görtemaker, Geschichte der Bundesrepublik Deutschland (2004), at 784. 
Programme deliveries to Somalia, ${ }^{6}$ without fail. However, the vast area of operation of Somali pirates who had started using motherships in 2008-2009 to venture further and further into the Indian Ocean ${ }^{7}$ made it apparent that even the combined (military) engagement of all nations willing to participate would fall significantly short of being able to guarantee the security of all trade vessels.

\section{Development towards a Legal Reform}

This set the stage for ship owners becoming more vocal about their situation and engaging with the public to build up pressure on the political actors. In Germany, they quickly and vehemently pushed for further state action during the high time of piracy off the coast of Somalia. ${ }^{8}$ Understandably so, after all their ships were under attack and other countries provided 'their vessels' with further security measures, that is, by making the armed forces available for private ships in the case of the Netherlands ${ }^{9}$ or by opening ways to allow ship owners to employ armed guards for their vessels as was the case, for example, in Greece and Denmark. ${ }^{10}$ At this point of time in Germany, politics and the shipping industry had been at odds with each other for a while. Germany, being the largest container ship-owning country, is widely seen as a global maritime player. ${ }^{11}$ However, while many shipping companies are seated in Germany, German ship owners traditionally resort to flags of convenience. ${ }^{12}$ Consequently, the size of its flag has never

6. See the first indent of Art. 1(1) of the EU Joint Action 2008/851/CFSP of 10 November 2008.

7. See e.g. A. Palmer, The New Pirates (2014), at 167 et seq.

8. See e.g. H. Friederichs, 'Reeder fordern Ausweitung des Anti-PiratenEinsatzes', Zeit Online, available at: https://www.zeit.de/online/ 2009/18/piraten-tagung (last visited 22 June 2009).

9. See the contribution by Paul Mevis in this volume.

10. See the contribution of Christian Frier in this volume; for the whole development, see also Y. Dutton, 'Gunslingers on the High Seas: A Call for Regulation', in J. Basedow, U. Magnus \& R. Wolfrum (eds.), The Hamburg Lectures on Maritime Affairs 2011-2013 (2014) 251, at 274 et seq.

11. See UNCTAD, Review of Maritime Transport 2018 (2018), 29 et seq.

12. See C. Koenig and D. König, in von Mangoldt/Klein/Starck, Grundgesetz, Art. 27, paras. 8, 12; for the long-standing practice of using flags of convenience, see e.g. B.A. Boczek, Flags of Convenience (1962); E. Osieke, 'Flags of Convenience Vessels: Recent Developments', 73(4) AJIL 604-27 (1979); D. König, 'Flags of Convenience', in R. Wolfrum (ed.), Max Planck Encyclopedia of Public International Law online edition (2008). This practice is the (unintended) consequence of Art. 91(1) sentence 2 UNCLOS mandating a genuine link between the flag state and the ship flying its flag, but not defining the concept. It has since been construed widely by the International Tribunal for the Law of the Sea in its judgments SAIGA (No. 2) Case (Saint Vincent and the Grenadines v. Guinea [Merits]), judgment of 1 June 1999, paras. 75et seq., 83 and Grand Prince Case (Belize v. France [Prompt Release]), judgment of 20 April 2001, paras. 82et seq.; Virginia G Case (Panama v. Guinea-Bissau), judgment of 14 April 2014, paras. 108 et seq., 110, 113; Available at: https://www.itlos.org/en/cases/list-of-cases; see C. Koenig and D. König, in von Mangoldt/Klein/Starck, Grundgesetz, Art. 27, para. 7 really reflected Germany's status as a major player in the field. There have been political agreements between the German government and the shipping industry, in which the political players promised better (financial) conditions in numerous ways for German companies, if they agreed to increase the number of ships flying the German flag. ${ }^{13}$ Yet, with the global economic crisis still ongoing in 2010, ship owners were generally hesitant to fulfil such commitments due to the higher costs associated with the German flag, and used piracy, especially the perceived inaction of the German government, as an explanation. They also used this argument as a lever to push for further state action. ${ }^{14}$ At this point, many German ship owners had already started employing armed security personnel to protect their ships, which sailed under flags such as Liberia, ${ }^{15}$ a flag renowned for being very forthcoming with allowing armed personnel.

Against this backdrop, a public discussion ensued. The main union of the Federal Police positioned the Federal Police as a possible key actor touting their ability to train vessel protection detachments (VPD) and offer police protection to German-flagged vessels. ${ }^{16}$ The Federal Police (former Bundesgrenzschutz, the German border police) was still recovering from a loss in significance after the German reunification and the creation of Europe's Schengen Area, which made new areas of responsibilities attractive. Furthermore, it could legally rely on $\S 6$ Bundespolizeigesetz (Act on the Federal Police), awarding the Federal Police broad jurisdiction including antipiracy measures and arguably VPD services. ${ }^{17}$ Such a step also would have added to the appeal of the German flag. However, factually, the Federal Police were lacking the equipment and trained personnel for such specific duties, and it soon became clear that both deficiencies would not be remediable on short notice. ${ }^{18}$ The German Armed Forces, which - in contrast to the Federal Police - already had the capability to provide VPD services, were lacking personnel also, seeing that they calculated the number of soldiers needed to protect one vessel as being between ten and twelve ${ }^{19}$

13. See e.g. O. Preuß and R. Zamponi, 'Schwarz-Rot-Streit: Konflikt unter deutschen Reedern', Hamburger Abendblatt, 31 December 2010, available at: http://bit.ly/2DNVMEM

14. See e.g. M. Lutz, 'Reeder verlangen von Regierung mehr Schutz vor Piraten', WeltOnline, 11 August 2011, available at: https://bit.ly/ 2Qfv9BC.

15. P. Hagen, 'German Owners Flag Out to Carry Private Security Forces', Lloyd's List, 15 June 2010.

16. See e.g. B. Witthaut, 'Einsatz der Bundespolizei am Horn von Afrika', BehördenSpiegel, 8 February 2012, available at: http://bit.ly/2BISKDF; M. Lutz, 'Polizei fordert 500 Soldaten zur Piraten-Bekämpfung', Welt, 10 August 2011, available at: http://bit.ly/2D9LeP8.

17. The norm states: 'Without prejudice to the competence of other authorities or of the armed forces, the Federal Police shall take the measures outside the German territorial sea to which the Federal Republic of Germany is entitled under international law. This does not apply to measures assigned by federal law to other authorities or departments or reserved exclusively for warships.'

18. See e.g. Walter, 'Einsatz der BPol am Horn von Afrika derzeit nicht darstellbar', BehördenSpiegel, 16 February 2012, available at: http://bit.ly/ 20 Djj84.

19. 'Schutz durch Soldaten auf dem Prüfstand', MaritimHeute.de, 17 December 2010 (article on file with the author); the Federal Police 
a number too large to present a realistic option for ship owners. Consequently, the pressure was building on the political actors. Would desperate Somalis with their small skiffs and rusty (albeit dangerous) guns be enough to result in an all-too-public display of the inability of the German government to protect its trading fleet's vessels? In this situation, the political actors aligned with the international tendency to support privately contracted armed guards on commercial vessels. ${ }^{20}$ This stance was prone to significant controversy in Germany. There were well-founded worries that such a move would escalate the phenomenon of piracy, since the pirates had seldom used their guns on board the vessels, knowing they would not meet armed resistance there. ${ }^{21}$ In the same vein, members of the ATALANTA operation warned that their work would become more complicated, if armed guards of varying qualities would be inserted into the equation, for example, in hostage situations. ${ }^{22}$ Furthermore, the image of private armed guards on trade vessels in shooting battles with pirates while the crew and possibly passengers or potentially hazardous cargo were on board was unattractive to say the least.

The nevertheless swift passing of the legal reform had different reasons. First, there was the already described lack of alternatives. The government was cornered by the calls for action from the maritime industry, which were amplified by the publics' concern over shocking displays of destruction on the hijacked vessels and the trauma caused to mariners who fell victim to pirate attacks. $^{23}$ While the opponents of such a legislative reform could find numerous arguments against allowing private armed guards, it was hard (and still is) to rally behind a position which provides no viable alternative to protect German trade vessels from pirate attacks. However, the real driver for reaching a swift political agreement on such a controversial topic was that there was general agreement about the deficiency of the legal framework as it was. Contrary to the public perception and political statements, ${ }^{24}$ rather than outlawing private

also calculated ten to twelve police officers to counter pirate attacks effectively, see Walter, above n. 18.

20. See T. Wiegold, 'Immer mehr private Sicherheitsteams gegen Piraten', 29 June 2011, available at: http://augengeradeaus.net/2011/06/imermehr-private-sicherheitsteams-gegen-piraten; for the international tendency, see Dutton, above n. 10, at 274 et seq.; see also the representation of IMO's evolving position on the issue, available at: http:// www.imo.org/en/OurWork/Security/PiracyArmedRobbery/Pages/ Private-Armed-Security.aspx

21. See D. König and T.R. Salomon, 'Private Sicherheitsdienste im Einsatz gegen Piraten', Rechtswissenschaft (RW) 303, at 331 (2011).

22. D. Osler, 'EU NAVFOR Warns Private Security Will Complicate Rescue Operations', Lloyd's List, 15 September 2010.

23. See the case of the Beluga Nomination, 'Die Piraten haben den Bootsmann erschossen', FAZ, 1 February 2011, available at: http:// www.faz.net/-gqi-daq.

24. The former maritime coordinator of the German government famously stated that the traffic lights would be changed from red to yellow on the issue of maritime security providers, T. Wiegold, 'Private gegen Piraten: "Wir stellen die Ampel von Rot auf Gelb"', augengeradeaus.net, 20 July 2011, available at: http://augengeradeaus.net/ 2011/07/private-gegen-piraten-wir-stellen-die-ampel-von-rot-aufgelb. armed guards on trade vessels, the legal framework as it stood actually permitted their use without providing adequate measures of quality control. ${ }^{25}$

\section{Legal Framework before 2013}

While the phenomenon of armed security personnel on trade vessels was new, the existing national legislation on security guards, especially $\S 34$ a of the Trade Regulation Act (Gewerbeordnung, in the following: GewO) and $\S 28$ Weapons Act (Waffengesetz, in the following: WaffG), applied to private armed guards on vessels flying the German flag. The flag state principle means that the jurisdiction of the flag state applies to a ship flying its flag. Furthermore, the aforementioned norms were not limited to the German territory. ${ }^{26}$ The following segment focusses on the law as it was until 2013, in order to allow a side-by-side view of the law before and after the legislative overhaul to illustrate the far-reaching effects of the reform.

\subsection{Starting and Running a Security Company Pursuant to $§ 34 a$ GewO}

\subsubsection{Basic Requirements to Start and Run a Security Company}

Pursuant to $\S 34 \mathrm{a}(1)$, sentence 1 , GewO, the commercial provision of protection for the life and property of people or businesses was subject to government authorisation. ${ }^{27}$ \$ $34 \mathrm{a}$ GewO in principle awarded the competent German authorities discretion (Ermessen) to authorise the owner of a company offering protection services. However, if the authorities had grounds to assume that the person seeking such authorisation was 'unreliable', lacked the means and securities needed or could not produce a certificate, attesting that he or she has been instructed by the Chamber of Commerce and Industry, they were bound by law to deny their authorisation as provided by $\S 34 \mathrm{a}(1)$, sentence 3 , GewO. Furthermore,

25. See R. Brinktrine, 'Der Einsatz privater Sicherheitsdienste zum Schutz vor Piraterie und maritimen Terrorismus', in Stober (ed.), Der Schutz vor Piraterie und maritimem Terrorismus zwischen internationaler, nationaler und unternehmerischer Verantwortung (2010) 39, at 47 et seq.; König and Salomon (2011), above n. 21, at 319 et seq.; T.R. Salomon and S. tho Pesch, 'Das Zulassungsregime für bewaffnete Sicherheitsdienste auf Handelsschiffen', DÖV 760, at 762 (2013); C. Oehmke, Der Einsatz privater Sicherheitsdienste auf Handelsschiffen zur Abwehr gegen Piraterie (2017), at 441; Working Group of the Conference of the Ministers of the Interior, Bekämpfung der Seepiraterie, 29 November 2011, at 27, available at: https://www.innenminister konferenz.de/IMK/DE/termine/to-beschluesse/11-12-09/ Anlage14.pdf.

26. With further references König and Salomon (2011), above n. 21, at 319; see also Oehmke, above n. 25, at 441.

27. In this segment, the past tense will be used, as the law as it stood before 2013 is assessed. While many of those rules are still in force and still regulate the private security sector in Germany, after the newly introduced rules discussed as follows, they no longer apply to private maritime security, as the new rules are lex specialis, see Oehmke, above n. 25 , at 443 
if the requirements were fulfilled, that is, there were no grounds for refusal, the competent authorities were under a duty to grant the authorisation following from constitutional law's influences on $\S 34$ a GewO protecting everyone's occupational freedom and the freedom of commerce. ${ }^{28}$

A company owner authorised to offer protection services pursuant to $\S 34 \mathrm{a}(1) \mathrm{GewO}$ in turn was only allowed to employ people who were 'reliable' and could produce a certificate, attesting that they had been instructed by the Chamber of Commerce and Industry concerning their rights and obligations. Slightly higher requirements were in place for private security guards working in public areas, protecting retail shops against shoplifters and working as doormen in nightclubs. Those had to pass an exam pursuant to $\S 34 \mathrm{a}(1)$, sentence 5 , GewO, evidencing that they had sufficient knowledge of their rights and obligations under the law. ${ }^{29}$

In summary, apart from possibly having to pass a general knowledge examination, persons needed to fulfil three requirements to start and run a security company offering protection services. They had to be reliable, have the necessary means and securities (to get through the first six months ${ }^{30}$ ), be able to produce a certificate that they received instructions on their rights and duties and basic training concerning de-escalation and so on. Of course, reliability is a vague legal term, but it is regularly used for the regulation of all kinds of industries in the GewO, is sufficiently open to interpretation to allow it to be applied differently in different industries and has been given contours by the courts. In summary, persons are unreliable, when there are grounds to suspect that they are incapable or unwilling to fulfil their obligations and execute their work in a proper form. ${ }^{31}$ For the security industry, this has been held to be the case, for example, if a person running a security company has a criminal record, especially entailing convictions for assault or economic crimes. ${ }^{32}$ To ascertain this, the authorities may access the criminal records of a person. ${ }^{33}$

28. With further references König and Salomon (2011), above n. 21, at 320; U. Schönleitner, 'Erlaubnisbedürftiges Bewachungsgewerbe', in R. Stober and H. Olschok (eds.), Handbuch des Sicherheitsgewerberechts (2004) 191, at 194.

29. For a general overview, König and Salomon (2011), above n. 21, at 319 et seq.; D. König and T. R. Salomon, 'Fighting Piracy - The German Perspective', in P. Koutrakos and A. Skordas (eds.), The Law and Practice of Piracy at Sea (2014) 225, at 240 et seq.; for a closer focus on the statutory exam, F. Jungk and C. Deutschland, in J.C. Pielow (ed.), BeckOK GewO (2017), § 34a, para. 34 et seq. The content of the exam is regulated by Annex 4 to the Ordinance on the Guard Profession (Verordnung über das Bewachungsgewerbe), as published on 10 July 2003 (Bundesgesetzblatt [Federal Law Gazette, in the following: BGBI.] I 1378), last amended by Art. 1 of the ordinance of 1 December 2016 (BGBI. I 2692).

30. See F. Jungk and C. Deutschland, in J.C. Pielow (ed.), Beck-OK-GewO (2010), § 34a, para. 33

31. P. Marcks, in Landmann/Rohmer (ed.), Gewerbeordnung (2009), § 34a GewO, para. 29; Jungk and Deutschland (2017), above n. 29, para. 30.

32. Jungk and Deutschland (2017), above n. 29, para. 32.

33. This is today regulated in $\S 34 \mathrm{a}(1)$ sentence $5 \mathrm{GewO}$; § $34 \mathrm{a}(1)$ sentence 6 GewO also allows an information request to the local Office for the Protection of the Constitution, see Jungk and Deutschland (2017), above n. 29, para. 32 .

\subsubsection{Further Aspects of $\$ 34 a \mathrm{GemO}$}

$\S 34 \mathrm{a}$ GewO also authorised the Federal Ministry for Economic Affairs and Energy to issue ordinances, ${ }^{34}$ which was used in December 1995. ${ }^{35}$ This ordinance detailed, among other matters, mandatory insurance policies for security companies, the necessity of carrying special identification and the modalities of the instruction by the Chamber of Commerce and Industry pursuant to $\S 34 \mathrm{a}(1)$, sentence 3 , GewO as well as the examination needed pursuant to $\S 34 \mathrm{a}(1)$, sentence 5 , GewO, especially the number of hours this instruction takes and the subject matter it covers. ${ }^{36}$

$\S 34 \mathrm{a}(4) \mathrm{GewO}$ authorised the authorities to mandate a company to discontinue an employee because facts suggest that he or she is unreliable, that is, because of a recent criminal conviction. ${ }^{37} \S 34 \mathrm{a}(5)$ GewO explained in how far private security companies were allowed to use force. It outlined that private security providers may only exercise the rights enjoyed by all citizens, especially the right to self-defence, unless public powers have been conferred upon them, which was rarely the case. This was a general feature of the discussion leading up to the new regulation on maritime security providers. It is generally accepted on a constitutional law level that the state has the monopoly to use force. ${ }^{38}$ Thus, the question arose whether the use of privately contracted security providers would contradict or infringe upon this monopoly. In Germany, there is widespread agreement that this was not the case, since such guards do not exercise public powers or have public authority. ${ }^{39}$ Employing armed guards on board ships - from a legal standpoint - is no different from employing armed guards to protect a money transport to and from a bank in Germany. ${ }^{40}$ However, in the case of private armed guards protecting vessels there may be additional legal duties of the German state to regulate this industry. ${ }^{41}$

\subsubsection{State Oversight and Sanctions}

Security companies fell under the same regime of industrial inspection as other trades. Pursuant to this control regime, authorities could step in if a business was run without authorisation and mandate the closure of the business. ${ }^{42}$ If a business was run with an authorisation but the prerequisites for the authorisation were no longer met, that is, the business owner became unreliable,

34. $\S 34 \mathrm{a}(2) \mathrm{GewO}$

35. See above n. 29; see also Marcks, above n. 31, para. 35

36. Jungk and Deutschland (2017), above n. 29, para. 64.

37. See Jungk and Deutschland (2017), above n. 29, para. 71. This may also result in the revocation of an authorisation vis-à-vis the employer, since a misconduct of an employee may be attributable to the employer or reflect the employer's unreliability, see Marcks, above n. 31, at 40.

38. König and Salomon (2011), above n. 21, at 322 et seq.; Oehmke, above n. 25, at 386 et seq., both with further references.

39. See Working Group of the Conference of the Ministers of the Interior, above n. 25, at 27.

40. König and Salomon (2011), above n. 21, at 322 et seq.; see also J. Ennuschat, 'Der neue $\S 31$ GewO - ein Schritt zur Privatisierung der öffentlichen Sicherheit?' Gewerbearchiv 329, at 331 (2014).

41. For a discussion, see Oehmke, above n. 25 , at 412 et seq. and 435 et seq.

42. §15(2) GewO. G. Sydow, in J.C. Pielow (ed.), Beck-OK-GewO (2010), $\S 15$, para. 31 . 
the authorisation could be withdrawn ${ }^{43}$ and the business closure mandated. ${ }^{44}$

For the purposes of effective state oversight, the competent authorities could mandate the business owner to disclose information on certain aspects. ${ }^{45}$ Such a request could only be denied if a business owner would otherwise expose himself or herself or his or her own relatives to the danger of criminal prosecution. ${ }^{46}$ Moreover, authorities had the right to enter the premises of businesses during business hours to inspect the business records. ${ }^{47}$

The GewO also contained norms on sanctions, for example, if a business owner runs a security company without authorisation. Such behaviour was - and still is - an administrative offence which may result in a fine of up to 5,000 euros. ${ }^{48}$ The repetition of such behaviour may amount to a criminal offence pursuant to $\S 148$ no. $1 \mathrm{GewO}$ punishable with a fine or imprisonment of up to one year.

\subsection{The Prerequisites for the Provision of Armed} Security Pursuant to $\$ 28$ WaffG

Anyone who protected goods or people using weapons not only needed the authorisation pursuant to the GewO but also had to comply with the Weapons Act. The material prerequisites of the Weapons Act were a bit stricter in comparison to the relatively lax $\S 34 \mathrm{a}$ GewO, since armed protection results in a higher risk. A person seeking authorisation to protect people in an armed fashion first had to be reliable pursuant to $\S 5$ Weapons Act. This notion of reliability was a bit stricter or at least more detailed compared to that in $\S 34 \mathrm{a}$ GewO, because in contrast to the GewO, $\S 5$ WaffG outlined in some detail what it meant by reliability and did not leave it up to the executive and judicative branch to decide. For example, a person was deemed to be unreliable in the sense of the norm, if facts justified the assumption that he or she would handle weapons or ammunition carelessly. ${ }^{49}$

Other than having to prove reliability, a person wanting to offer armed protection also had to show the personal aptitude for the task, which is deemed to be lacking, for example, if facts justify the assumption that he or she is addicted to alcohol or other controlled substances. ${ }^{50}$ Furthermore, the person had to evidence their expertise with weapons. ${ }^{51}$ The details of how to prove expertise and which standards applied were outlined in secondary

43. Pursuant to the general rules, e.g. § 49 Verwaltungsverfahrensgesetz (VwVfG, Administrative Procedure Act) (or $\S 48 \mathrm{VwVfG}$, if the prerequisites of an authorisation pursuant to $\S 34 \mathrm{a}$ GewO were never met, but the authorisation was nevertheless granted); see B. Handan, 'Grundzüge des Gewerberechts', JA 249, at 253 (2007).

44. §15(2) GewO.

45. § 29(1) GewO

46. § 29(3) GewO

47. § $29(2)$ GewO

48. § 144(1) no. 1(f); (4) GewO

49. §5(1) no. 2(a) WaffC

50. § 6(1) sentence 1, no. 2 WaffG.

51. $\S 7$ WaffC. legislation. ${ }^{52}$ Usually, the participation in detailed courses and examinations were required. The WaffG also included an age restriction, resulting in a minimum age limit of eighteen years pursuant to § 2(1) WaffG.

Other than reliability, personal aptitude and expertise, a person furthermore had to evidence a need or necessity to use weapons pursuant to $\S 8$ WaffG. $\S 28 \mathrm{WaffG}$, which regulated the specific case of security guards, obliged security guards to demonstrate that the specific service they intended to offer required the use of arms, due to the circumstances of the single case, namely, the nature of the person or object under protection. ${ }^{53}$

The Weapons Act also restricted the kinds of weapons allowable under the law, ${ }^{54}$ for example, by disallowing weapons of war, especially automatic weapons. The German Federal Criminal Police Office had jurisdiction to decide in cases of doubt whether a weapon was allowable or not. ${ }^{55}$

If all prerequisites were fulfilled, a person was able to apply for permission to purchase and own a specific weapon. ${ }^{56}$ However, carrying a weapon necessitated a separate permission ${ }^{57}$ and yet another permission was needed to actually fire a weapon. ${ }^{58}$

\subsection{Interim Conclusion}

In conclusion, 34a GewO and $\S 28$ WaffG did not distinguish between privately contracted armed guards protecting trade vessels in high-risk areas and store detectives or nightclub bouncers. The rules applied to all kinds of armed guarding activities and did not fall short of applying to private maritime guards. ${ }^{59}$ This led to problematic results. On the one hand, the material standards ensuring that people offering armed protection to trade vessels were highly trained and skilled was lacking. ${ }^{60}$ On the other hand, the old law would have proven to be factually prohibitive. Mandating that maritime armed guards show up in person before a German Chamber of Commerce and Industry to be instructed in German on their rights and obligations under German law among other matters would have been impractical. The same applies for the need to obtain the necessary

52. General Order to the Weapons Act (Allgemeine Waffengesetz-Verordnung) of 27 October 2003 (BGBI. I 2123), last amended by Art. 2 of the Law of 30 June 2017 (BGBI. I 2133).

53. König and Salomon (2011), above n. 21, at 325, with further references.

54. § 2(2) WaffG; Annex 2 to the WaffG

55. $\S \S 2(5), 48(3)$ WaffG

56. §10(1) WaffG

57. § 10(4) WaffG; see A.V. König and C. Papsthart, in NomosKommentar WaffG (2012), §10, para. 11

58. § 10(5) WaffG, which does not apply in cases of self-defence; see König and Papsthart, above n. 57, para. 14. This requirement is still in place today, resulting in a prohibition to train the shooting of weapons at sea unless a permission pursuant to § 10(5) WaffG has been granted; see the information provided by the BAFA in the FAQ section on their webpage, 'Is it permitted to organise the weapons training on the high seas?', available at: http://www.bafa.de/EN/Foreign_Trade/Maritime_ Security/maritime_security_node.html (last visited 27 December 2017).

59. See the widely accepted definition of guard profession in Jungk and Deutschland (2017), above n. 29, para. 4 et seq. including the exercise of active personal care to intentionally protect a person or good against external threats.

60. Oehmke, above n. 25, at 441 . 
permission pursuant to the Weapons Act, again requiring mandatory classes in German. Such a procedural necessity would have proven at least extremely cumbersome for companies from foreign countries, much more so, if they in turn employed maritime guards who came from yet different countries.

Overall, one would have to assess the legal regime established by $\S 34 \mathrm{a}$ GewO and $\S 28 \mathrm{WaffG}$ as fundamentally unfit for the dangerous practice of protecting vessels with armed guards against piratical attacks. 'Reliability' alone is insufficient as the main quality standard for armed guards on trade vessels, and the GewO did not provide for much more. In addition, the regulatory system lacked a proper regime of state control and sanctions in that it did not address the challenges of regulating an industry that operated far away from German territory. Furthermore, it failed to provide the procedural standards needed to regulate an international industry made up mainly of companies from foreign countries.

This regulatory framework left the government with two options:

1. Leave the law as it is and allow armed guards on board trade vessels without mandating meaningful vetting and quality control, while factually discouraging the practice by upholding the cumbersome national authorisation process with its focus on instructions and examinations in the German language. This option would have most likely resulted in numerous violations of the GewO and WaffG norms by ship owners or - much more likely - a further decrease in the number of vessels flying the German flag.

2. Regulate privately contracted maritime security companies and thus attempt to introduce a normative framework tailor-made for the regulation of such a dynamic and international trade.

It chose the second alternative.

\section{Legal Reform of Maritime Security Providers in German Law}

In doing so, German legislators had to deal with the tension that typically exists when regulating the maritime industry. On the one hand, introducing high-quality standards for armed guards operating on German vessels could drive ship owners away from the German flag, since rendering the German legislation inapplicable requires no more than that - a change of flags. Thus, any such regulation would have been a 'paper tiger', a regulation of merely, if at all, theoretical value. Introducing low-quality standards, on the other hand, would not have increased the security of trade vessels, but factually would have been to its detriment, for example, by allowing 'cowboys' 1 with guns on board German-flagged vessels. Moreover, such a move would have significantly shifted the burden of quality control to the ship owners. Without being able to rely on high-quality standards set by the German government they would have had to adopt their own vetting and quality assurance mechanisms to make sure that they contract only suitable and reliable security companies or otherwise put their crews, vessels and cargo at risk and face possible damage claims. ${ }^{62}$

With the new legislation, Germany chose a middle path. The Bundestag voted to amend the GewO and the WaffG. However, it departed significantly from the traditional German way of regulating businesses. Even the competent authorities, the Federal Ministry for Economic Affairs and Energy and the Federal Ministry of Transport and Digital Infrastructure acknowledged that the new $\S 31$ GewO, which was introduced in 2013, ${ }^{63}$ established factually and, legally speaking, a totally new procedure for a trade license. ${ }^{64}$

Pursuant to the new system, maritime security providers need to obtain a license issued by the Federal Office for Economic Affairs and Export Control (BAFA) in consultation with the Federal Police. ${ }^{65}$ The key difference between the new licensing system and other systems of trade licenses in German law is the corporate approach. In the past, the $\mathrm{GewO}$ always focussed on the person, that is, the company owner and his or her employees, with a view to ascertaining their reliability. $\S 31$ GewO established a government approval system that focusses on the company itself. Instead of the company owner and the employees having to prove their reliability, the new regulatory system has the aim to ascertain whether the company has put the necessary organisational processes in place to safeguard that only reliable and suitable employees will undertake vessel protection services. To this end, the BAFA will, for example, not mandate a certain kind of training for new guards; it will simply look at the security and training concept, which the company has to document and make available during the licensing procedure, and evaluate whether based on this procedure it is sufficiently safeguarded that only reliable, apt and competent people are

61. The term 'cowboys' is often used as a synonym for unreliable, possibly trigger-happy, security guards not accustomed to the maritime environment; see e.g. Dutton, above n. 10, at 268; but the term also finds use in the academic discussion on private military and security companies; see K. Carmola, Private Security Contractors and New Wars (2010), at 13.

62. See Salomon and tho Pesch, above n. 25, at 762; M. Mudric, 'Armed Guards on Vessels: Insurance and Liability', 50 Comparative Maritime Law 217-68 (2011), available at: http://hrcak.srce.hr/file/114368.

63. Gesetz zur Einführung eines Zulassungsverfahrens für Bewachungsunternehmen auf Seeschiffen of 4 March 2013 (BGBI. I 362), last amended by the Law of 24 April 2013 (BGBI. I 930).

64. Erfahrungsbericht des Bundesministeriums für Wirtschaft und Energie im Benehmen mit dem Bundesministerium für Verkehr und digitale Infrastruktur und dem Bundesministerium des Innern, BT-Drs. 18/6443 of 16 October 2015, at 2 .

65. §31 $(1,2)$ GewO. 
going to be deployed to trade vessels. ${ }^{66}$ A slight departure from the corporate approach is made for the assessment of the management. The reliability, personal aptitude and competence of the management have to be evidenced during the licensing procedure. ${ }^{67}$

Aside from the GewO, the Weapons Act also has been amended to make a similar approach possible.

\subsection{The Basic Requirements for Obtaining a License}

The new $\S 31$ GewO mandates that security companies planning to guard vessels sailing under German flag seawards of the German Exclusive Economic Zone against external threats ${ }^{68}$ need a license issued by the BAFA in consultation with the Federal Police ${ }^{69}$ regardless of where the security company is seated. Moreover, any German security company wishing to provide such services needs the same license regardless of the flags of the vessels on which they operate. ${ }^{70}$ While $\$ 34$ a GewO remains in force, $\S 31$ GewO today applies as lex specialis to security companies offering protection to trade vessels in the sense described previously. ${ }^{71}$

\subsubsection{The Requirements Pursuant to $\$ 31 \mathrm{Gem} O$ for Maritime Security Companies}

$\S 31$ GewO lists specific requirements regarding the internal organisation and procedures of the companies applying for the license, and it also seeks to ensure technical and personal reliability, personal aptitude and competence of the persons involved. ${ }^{72}$ However - in line with the corporate approach - it is not the German authorities that scrutinise the personal reliability of the people involved, but the company itself, with the German authorities merely assessing, if the internal organisation of said company guarantees that their employees meet the requirements. As such, the license is to be refused, pursuant to $\S 31(2)$, sentence 3 , no. 1 GewO, when the company seeking to be licensed does not fulfil the requirements concerning the operational organisation and internal procedures needed to ensure that the people involved in the provision of security services are reliable and demonstrate the necessary personal aptitude. Grounds for refusal pursuant to $\S 31(2)$, sentence 3 , no. 2, GewO, are also given, if the management personnel does not demonstrate the necessary professional and personal competence and reliability or if the company fails to produce the required business liability insurance. ${ }^{73}$ Other relevant requirements, which are much

66. König and Salomon (2014), above n. 29, at 242; Salomon and tho Pesch, above n. 25, at 763; H. Jessen, 'Der Einsatz privater bewaffneter Sicherheitsunternehmen auf Handelsschiffen unter deutscher Flagge', RdTW 125, at 130 et seq. (2013); Oehmke, above n. 25, at 447 et seq.

67. §31(2), sentence 3, no. 2 GewO; see Oehmke, above n. 25, at 455

68. § 31(1) GewO.

69. §31(2) GewO

70. Salomon and tho Pesch, above n. 25, at 763; see also VGH Kassel, Order of 21 July 2015 - 8 B 1916/14 - ECLI:DE:VGHHE:2015:0721. 8B1916.14.0A, para. 2.

71. §31(2), sentence 4, GewO; see also Oehmke, above n. 25, at 443 .

72. §31(2), sentence 3, no. 1, GewO.

73. Regarding the latter as a ground for refusal see $\S 31(2)$, sentence 3 , no. 3, GewO. more detailed and intricate, are laid down in secondary legislation, namely, the Ordinance on the Licensing of Security Companies on Ocean-Going Sea Vessels (in the following: Licensing Ordinance ${ }^{74}$ ) and the Implementing Ordinance for the Ocean-Going Vessel Security Ordinance (in the following: Implementing Ordinance ${ }^{75}$ ).

Whereas $\S 31$ GewO safeguards that every security company operating from Germany or on German-flagged vessels will need to be licensed pursuant to the new regime, an amendment to the German Ordinance on Shipboard Security Measures (See- Eigensicherungsverordnung ${ }^{76}$ ) establishes a duty of ship owners sailing under the German flag and wishing to deploy armed guards to only employ those with a license pursuant to $\S 31$ GewO. ${ }^{77}$ In order to safeguard that a sufficient number of such companies is available, the duty pursuant to the German Ordinance on Shipboard Security Measures entered into force about nine months after the licensing regime. ${ }^{78}$ The ordinance obliges ship owners and operators to apply for an annex to the ship security plan mandatory pursuant to the International Ship and Port Facility Security (ISPS) Code. This annex needs to detail that armed security guards will be used, that those guards are licensed pursuant to $\$ 31 \mathrm{GewO}$ and that they will keep to the 'Revised Interim Guidance to Shipowners, Ship Operators and Shipmasters on the Use of Privately Contracted Armed Security Personnel on Board Ships in the High Risk Area'79 published by the International Maritime Organization (IMO). ${ }^{80} \mathrm{By}$ doing so, the ordinance factually makes adherence to this soft law instrument mandatory.

Employing guards without a license pursuant to $\S 31(1,2)$ GewO constitutes an administrative offence by the ship owner, which may result in a fine of up to 15,000 euros being imposed. ${ }^{81}$ This procedure is administered by the Federal Maritime and Hydrographic Agency (Bundesamt für Seeschifffahrt und Hydrographie $[\mathrm{BSH}])$. Such a violation will lead to the revocation of the approval of the annex to the ship security plan. ${ }^{82}$

74. Ordinance of 11 June 2013 (BGBI. I 1562).

75. Ordinance of 21 June 2013 (BGBI. I 1623).

76. Ordinance of 19 September 2005 (BGBI. I 2787), last amended by Art. 3 of the Ordinance of 1 March 2016 (BGBI. I 329).

77. See $\S 7(2 a)$, sentence 1, no. 2(b), and sentence 3, German Ordinance on Shipboard Security Measures.

78. Salomon and tho Pesch, above n. 25, at 761.

79. MSC.1/Circ.1405/Rev. 2, 25 May 2012, as published by the Federal Ministry of Transport, Building and Urban Development, as it then was, in Verkehrsblatt 2013, at 640.

80. $\S 7(2 a)$, sentence 1, no. 2(a) and (b), German Ordinance on Shipboard Security Measures.

81. Allgemeine Verwaltungsvorschrift für die Erteilung von Buß - und Verwarnungsgeldern für Zuwiderhandlungen gegen strom - und schifffahrtspolizeiliche Vorschriften des Bundes auf Binnen - und Seeschifffahrtsstraßen sowie in der ausschließlichen Wirtschaftszone und auf der Hohen See (Buß - und Verwarnungsgeldkatalog Binnen - und Seeschifffahrtsstraßen - BVKatBin-See), 2015, para. 37.103200 (at 333).

82. $\S 7(4)$ German Ordinance on Shipboard Security Measures. 


\subsubsection{Ordinance on the Licensing of Security Companies on Ocean-Going Sea Vessels}

The basic norm, § 4(1) Licensing Ordinance, regulates that in order to apply for a license, a company has to set up and document a proper operational framework that ensures compliance with legal requirements and maintain this framework during the term of the license. The company furthermore has to define, document and regularly update appropriate procedures for planning and conducting operations at sea, such as the composition and qualification of the security personnel, procedural rules on the use of force and weapons and the monitoring of the security operatives on board ${ }^{83}$ In addition, the company has to regulate the duties of its security operatives through a general standing order, operationsspecific standing orders and shift scheduling ${ }^{84}$ and ensure that the security operatives are equipped with appropriate, serviceable equipment for carrying out their security function. ${ }^{85}$ Concerning the employees actually exercising security functions, the company has to ensure that guards are reliable, ${ }^{86}$ are at least 18 years old,${ }^{87}$ have the necessary personal aptitude ${ }^{88}$ and possess the necessary competence. ${ }^{89}$ The company also has to name a so-called designated executive, who acts as a link between the company and the German authorities. ${ }^{90}$ Regarding this executive, the company has to submit records showing that he or she, as the person who is responsible to ensure compliance with the regulation, ${ }^{91}$ also fulfils these requirements. ${ }^{92}$ The company wishing to be licensed also has to produce proof of having a liability insurance policy that fulfils the requirements pursuant to $\S 12$ of the Licensing Ordinance and submit a company profile containing a description of the market position of the security company in the field of maritime security. ${ }^{93}$

\subsubsection{Implementing Ordinance for the Ocean-Going Vessel Security Ordinance}

The Implementing Ordinance first regulates the appointment procedure of the designated executive $e^{94}$ and the organisational structure of the company in question. ${ }^{95}$ In doing so, it establishes relatively detailed

83. $\S 5(1)$ Licensing Ordinance.

84. $§ 5(2)$ Licensing Ordinance.

85. § 6(1), sentence 1, Licensing Ordinance.

86. $\S 8$ Licensing Ordinance.

87. § 7, no. 2, Licensing Ordinance.

88. §9 Licensing Ordinance.

89. § 10 Licensing Ordinance.

90. The BAFA on its webpage mentions the designated executive as a 'role model for the security personnel', who must 'possess the same level of knowledge'; see the FAQ section on the BAFA webpage, 'Does the executive has to possess the full level of knowledge pursuant to section 10 Ordinance on the Licensing of Security Companies on Ocean-Going Sea Vessels already at the time when the application is filed or is it possible to submit the evidence later, probably after licensing?', available at: http://www.bafa.de/EN/Foreign_Trade/Maritime_Security/maritime _security_node.html.

91. § 4(1), sentence 2 , no. 1, Licensing Ordinance.

92. § 11(2-4) Licensing Ordinance.

93. § 2(2) Licensing Ordinance.

94. § 1 Implementing Ordinance.

95. § 2 Implementing Ordinance. standards. First, the company has to establish areas of responsibility of the specific guards on board a vessel and of other employees. ${ }^{96}$ It also has to explain how the company will deal with cases of absence. ${ }^{97}$ The Implementing Ordinance also mandates that the security team of a vessel has to be sufficiently staffed, requiring a minimum of four operatives, but opening the possibility to require more team members whenever the risk assessment shows a necessity for a higher headcount. ${ }^{98}$ The company also has to show that it has documented criteria to determine staffing requirements, including role distribution within the security team. It lays out that each vessel protection team must consist of a) a team leader, b) a deputy team leader, c) guards and d) a trained paramedic; however, b), c), and d) may be performed by the same person, as long as the team does not fall short of the minimum number of team members. ${ }^{99}$

While the Licensing Ordinance regulates the material requirements, which the members of a security team have to fulfil, the Implementing Ordinance sets standards for the personnel selection and review process, which the company has to follow to ensure that the material requirements are continuously fulfilled. ${ }^{100}$ It also lays down some rules for the training of a company's employees, ${ }^{101}$ for example, a minimum of four weapons training sessions a year, which may not be more than six months apart. ${ }^{102}$ How these trainings are conducted is again up to the company. ${ }^{103}$ Furthermore, companies have to introduce internal control, ${ }^{104}$ documentation $^{105}$ and communication processes, for example, to safeguard the immediate report of imminent or observed misconduct to the designated executive. ${ }^{106}$

The Implementing Ordinance also regulates the duty of the company to have deployment procedures in place, which include a consideration of the IMO's 'Revised Interim Guidance to Shipowners, Ship Operators and Shipmasters on the Use of Privately Contracted Armed Security Personnel on Board Ships in the High Risk Area', and observance of the 'Best Management Practices for Protection against Somalia Based Piracy' (BMP). ${ }^{107}$ The deployment procedures also have to safeguard the strict avoidance of physical force and the use of weapons. Exceptions may only be made when

96. The necessity to make available a sufficient number of employees around the clock on land to maintain operations is regulated in $\S 1(1)$ no. 3 , of the Implementing Ordinance. For the requirement to legal advice around the clock see $\S 8$ of Implementing Ordinance.

97. § 2(1), no. 1, Implementing Ordinance.

98. § 2(1), no. 2, Implementing Ordinance.

99. § 2(1), no. 2, Implementing Ordinance.

100. $\S 4$ and 5 Implementing Ordinance.

101. § 6 and 7 Implementing Ordinance.

102. $\S 7(2)$ Implementing Ordinance.

103. See the answer to the question, 'How and to what extent should the legal knowledge training be organized?', in the FAQ section on the BAFA webpage, available at: http://www.bafa.de/EN/Foreign_Trade/ Maritime_Security/maritime_security_node.html.

104. § 9 Implementing Ordinance.

105. § 10 Implementing Ordinance.

106. § 11 Implementing Ordinance as a whole, but especially § 11(1), no. 2 , Implementing Ordinance.

107. § 12(2) Implementing Ordinance. 
they are in accordance with the German legislation, particularly the rules on self-defence with special consideration given to appropriateness, necessity and proportionality of the defensive action. ${ }^{108}$ The Ordinance specifies:

If an attack is in progress and other milder defensive measures are unsuccessful or if their use is unpromising, the team leader gives the instruction - after the captain has expressly ordered it - to occupy the defensive positions and make preparations to fire. With consideration given to the general circumstances in individual cases, the following basic escalation levels are provided for:

1. warning shots into the air,

2. warning shots into the water in the vicinity of the attackers,

3. targeted shots at objects, particularly at the boat motor or hull,

4. as a last resort, if all milder defensive measures are ineffective, it is possible to use firearms directly against the attackers. ${ }^{109}$

It is noteworthy that master of a vessel (here: the captain) remains the final decision-maker. This was uncontroversial during the legislative process, since it is mandated by international and German law and its importance was universally supported. ${ }^{110}$ While the Implementing Ordinance thus gives directions on how to exercise the right to self-defence, the legal rules regulating the use of force, however, remain unchanged compared to the law before 2013. The new $\S 31(2)$, sentence 4 , GewO refers to $\S 34 \mathrm{a}(5) \mathrm{GewO}$ and thus clarifies that security guards working for BAFA-licensed companies are - just as bouncers in nightclubs - regularly limited to the right to self-defence. ${ }^{111}$ This has proven to be sufficient in practice, as the criminal law notion of selfdefence is quite permissive in German law. ${ }^{112}$ However, it has drawn criticism because such cases of professional or institutionalised self-defence are quite different from the cases the law originally meant to regulate by granting a right to self-defence. ${ }^{113}$ In addition, it has been a

108. § 12(4), sentence 2 , Implementing Ordinance.

109. § 12(4), sentences 4 and 5, Implementing Ordinance.

110. See e.g. Salomon and tho Pesch, above n. 25, at 766; R.E. Heller and H. Soschinka, 'Seepiraterie-Bekämpfung durch private Bewachungsunternehmen', NVwZ 476, at 479 (2013); Oehmke, above n. 25, at 201 et seq. with further references.

111. § $34 \mathrm{a}(5) \mathrm{GewO}$ refers to more legal bases and in fact more legal bases apply, e.g. the 'Hausrecht', allowing an owner of premises to exclude some people from using it and to expel them, as well as the 'rights' pursuant to § 34 German Penal Code and §§ 227-9, 904 German Civil Code. However, in maritime security cases, the right to self-defence and defence of others pursuant to $\S 32$ German Penal Code regularly is the only decisive legal basis for armed defence.

112. See for a maritime security-based study on this König and Salomon (2011), above n. 21, at 327 et seq.; Oehmke, above n. 25, at 484 et seq.

113. For a discussion, see Oehmke, above n. 25, at 394 et seq.; S. Kommer, 'Private Gefahrenabwehr auf Hoher See', DÖV 236, at 245 (2016); for a general discussion of the ratio legis of the right to self-defence in German law, see U. Kindhäuser, in U. Kindhäuser, U. Neumann \& H.U. Paeffgen (eds.), Strafgesetzbuch (2017) § 32, para. 7 et seq. topic of minor debate in German law whether there is a potential right of private guards to arrest (suspected) pirates. $^{114}$

The Implementing Ordinance also goes into the nittygritty details, regulating the minimum equipment a security team has to bring on board a vessel, including night vision device, range finder, binoculars, long firearms, short firearms (especially for confrontations with an attacker after the ship was boarded ${ }^{115}$ ), sufficient ammunition, ballistic helmets, camera, ballistic vests, radio equipment with microphone headset, satellite telephone, medical equipment as well as automatic life vests. ${ }^{116}$ Fines have been imposed for the failure to comply with these requirements. A case in point was a vessel protection team that was not equipped with short firearms. $^{117}$

Violations of the obligations outlined in the foregoing regularly are administrative offences penalised with a fine, which is administered by the BAFA. ${ }^{118}$ However, as the main and most punitive sanction available to the BAFA a license may be revoked pursuant to the general rules of German administrative law when the terms of the license have been violated by the license-holder. ${ }^{119}$

\subsection{Licensing Procedure}

The licensing procedure has been designed to meet the requirements of the international maritime industry. The licensing procedure can be undergone electronically, and the German authorities provide the necessary information and documents in English and largely accept the necessary documentation in English. ${ }^{120}$ In contrast to the old normative framework, there is no need for company employees or the company management to appear before the authorities in person. In order to accelerate the process, the BAFA has published a self-assessment checklist to allow companies a quick self-check, to determine whether they fulfil all requirements. ${ }^{121}$ The costs associated with applying for such a license are significant. An early estimation approximated the costs of a German company entering the market in the first year at around 1.1 million euros as initial cost

114. See e.g. Kommer, above n. 113, at 244, who regrettably misreads the study of König and Salomon (2011), above n. 21, as being of the opinion that armed guards have a right to arrest pirates pursuant to German law. The study merely argued - in the segment focussing on international law - that such an act would not in and of itself be an act of piracy pursuant to the UNCLOS definition, which mirrors the opinion of the ILC, see ILC, UN Doc. A/3159 (1956), at 283.

115. Erfahrungsbericht des Bundesamtes für Wirtschaft und Ausfuhrkontrolle im Einvernehmen mit dem Bundesamt für Seeschifffahrt und Hydrographie und der Bundespolizei, BT-Drs. 18/5456 of 1 July 2015, at 24.

116. $\S 14(2)$ Implementing Ordinance.

117. See BT-Drs. 18/5456 of 1 July 2015, above n. 115, at 24

118. § 144(5) GewO; examples of such misconduct are the intentional or negligent violation of the duty to obtain a license, which may result in fines up to 50,000 euros ( $\$ 144(1)$ no. 2 and (4), GewO) and violations of the Licensing Ordinance, which may be penalized with fines up to 5,000 euros (§ 144(2) no. 1, GewO and § 16 Licensing Ordinance).

119. $\S 49 \mathrm{VwVfG}$

120. BT-Drs. $18 / 5456$ of 1 July 2015 , above n. 115 , at 9 .

121. The checklist is available in the English language at http:// www.bafa.de/SharedDocs/Downloads/EN/Foreign_Trade/ ssb_self_assessment_checklist.html. 
and subsequently around 100,000 euros as annual cost. For companies in the market, but not working with an internal process manual, the costs for an application are estimated at 103,500 euros, while a company in the market already working with such a process manual will likely face significantly lower expenses. The annual training costs are estimated to be around 10,000 euros. $^{122}$

If a company applies for a license, it does so by filling out the electronic application form on the BAFA webpage and attaching the necessary documents. ${ }^{123}$ Due to the large volume of documents received in an application, the licensing process takes time. All in all, the procedure regularly takes 'some months' according to the BAFA. ${ }^{124}$ While the process has in the past been slowed down by the failure of companies to submit necessary documents, another factor for a time delay is the fact that the subject matter is deemed as being vulnerable to corruption. Because of this, each application undergoes a primary examination and then a secondary audit by another government employee. ${ }^{125}$ The necessary evaluation of the company's insurance to ascertain whether it fulfils the requirements of $\$ 12$ Licensing Ordinance was identified as being another source for time delay. To alleviate this factor, the insurer can submit a confirmation letter to the BAFA. ${ }^{126}$

In the authorisation process, the BAFA consults closely with the specialised maritime branch of the Federal Police based on an administrative arrangement which specifies that the Federal Police issue a recommendation in the licensing process and the BAFA considers it before deciding on granting the license. ${ }^{127}$ A stronger role of the Federal Police, for example, as the authority competent to grant the licenses or at least as an authority with a veto power was rejected during the legislative process. ${ }^{128}$

The period of validity of a BAFA license is two years. ${ }^{129}$ A previous draft of the new legislation proposed one year as a possible duration to guarantee a higher degree of control and regularity of inspection, but the longer period was deemed necessary to balance practical demands and meaningful oversight. ${ }^{130}$ Recent demands from the maritime industry to extend the duration to three years were unsuccessful. This was mainly because BAFA acknowledges the need to keep the duration at two years, in order to ensure a regular and meaningful control over the companies, which is easier realised dur-

122. All estimates taken from the draft legislation, Entwurf eines Gesetzes zur Einführung eines Zulassungsverfahrens für Bewachungsunternehmen auf Seeschiffen, BT-Drs. 17/10960 of 10 October 2012, at 3.

123. The application page is accessible at https://fms.bafa.de/BafaFrame/ bewachung.

124. BT-Drs. $18 / 5456$ of 1 July 2015, above n. 115 , at 10.

125. Ibid

126. Ibid

127. BT-Drs. $18 / 5456$ of 1 July 2015 , above n. 115 , at 12 .

128. Salomon and tho Pesch, above n. 25, at 763; Oehmke, above n. 25, at 446.

129. § 3 Licensing Ordinance.

130. See Salomon and tho Pesch, above n. 25, at 766; König and Salomon (2014), above n. 26, at 243. ing the licensing process than by the state oversight mechanisms in place. ${ }^{131}$

\subsection{Weapons Act}

The Weapons Act has been amended in order to go along with the corporate approach of the new $\$ 31$ GewO. ${ }^{132}$ Pursuant to the new regulatory framework, armed security companies operating on German-flagged vessels still need a weapon owner's license to possess the weapons needed to carry out their duties. ${ }^{133}$ While the BAFA is competent to license security companies pursuant to $\S 31 \mathrm{GewO}$, the authorities of the Free and Hanseatic City of Hamburg are competent to issue the permit to the applying company that is necessary under the Weapons Act. ${ }^{134}$ The authorities may exchange information with the BAFA, resulting in a much better information basis of the Hamburg authorities, since the BAFA regularly will have a much more detailed picture of the companies applying for a license. ${ }^{135}$

Pursuant to $\S 28 \mathrm{a}$ WaffG, the company has to apply for a permit, which, if granted, allows security operators and their personnel to acquire, possess and carry guns and ammunition on ocean-going vessels flying the German flag. ${ }^{136}$ In practice, the company manager has to produce an identity card or passport and a police clearance certificate (if he or she is a foreign national ${ }^{137}$ ). With the application, the company also has to make available copies of identification documents, employment contracts and police clearance certificates (in case of foreign nationals) of the security guards, as well as their certificates of weapons expertise and documents showing that they have knowledge of German arms legislation and related laws and regulations. Furthermore, the executive staff also have to provide proof of weapons expertise and knowledge of German arms legislation and related laws and regulations. Last, the company has to produce evidence that weapons are kept safely at the company and a safekeeping policy for the storage of weapons on board trade vessels is in place. ${ }^{138}$

The reformed regulatory framework is parallel to the $\S 31$ GewO. While in the past the permit could only be obtained by people having to appear before the competent authorities, providing evidence that they fulfil the legal requirements, the permit now is addressed to the company, encompasses the staff, and it is the company's

131. See BT-Drs. $18 / 6443$ of 16 October 2015, above n. 64, at 7-9; for a discussion of state oversight mechanisms under the regime, see Section 4.5 in this article.

132. Beschlussempfehlung und Bericht, BT-Drs. 17/11887 of 12 December 2012, at 21.

133. § 10(1) WaffG; see also Oehmke, above n. 25, at 457

134. $\S 48(1)$, sentence 2, WaffG. In case of German security companies, the authorities of Hamburg consult with the local authorities at the seat of the company, § 28a(5) WaffG.

135. § 28a(3), sentences 3 and 4, WaffG.

136. § $28 \mathrm{a}(1)$, sentence 1, WaffC

137. If a German national applies for a permit, the local authorities have the right to obtain such a certificate from the competent German authorities.

138. For these practical aspects of the authorisation process, see the BAFA webpage under 'Application Procedure' - 'License under the Weapons Act', available at: http://www.bafa.de/EN/Foreign_Trade/Maritime_ Security/maritime_security_node.html. 
duty to safeguard that the legal requirements are met. ${ }^{139}$ Pursuant to $\S 28 \mathrm{a}(1) \mathrm{WaffG}$, the weapons permit 'shall be issued subject to conditions requiring the operator' to employ as security personnel only persons who meet the requirements given in $\S 4(1)$ nos. 1 through 3 (meaning the persons in question are older than eighteen, are reliable and have the personal aptitude for the task and have the necessary expertise with weapons). A further condition of the permit is that the company will inform the responsible authority within a period of time to be determined by that authority as to which persons have been assigned as armed guards. ${ }^{140}$ Last, the company is obliged 'at the request of the responsible authority, to present evidence demonstrating that the persons assigned these tasks meet the requirements' mentioned above. ${ }^{141}$ Concerning the only additional requirement, the necessity to use guns for the protection offered, this necessity is assumed by law for companies licensed pursuant to $\$ 31 \mathrm{GewO}{ }^{142}$

Not only the procedure but also the content of the traditional requirements for obtaining a weapons permit, reliability, aptitude, competence and necessity are modified to fit different settings. For example, the specialised knowledge necessary pursuant to $\S 7(2)$ WaffG 'shall be oriented on the special requirements for deployment on ships at sea' as far as permits under $\S 28$ a WaffG are concerned. ${ }^{143}$

The weapons permit has the same duration as the license pursuant to $\S 31 \mathrm{GewO}^{144}$ and includes the permit to bring the weapons on board a vessel pursuant to § 29 WaffG. ${ }^{145}$

The type of weapons that are permissible has remained unchanged under the new legislation. ${ }^{146}$ Consequently, the use of war weapons in accordance with the Annex 2 to the War Weapons Control Act, especially automatic weapons, remains illegal. ${ }^{147}$ This aspect was largely uncontroversial during the legislative proceeding in Germany and seems to be in contrast to the approach in other nations. ${ }^{148}$

\subsection{Recognition of Other Licenses}

To safeguard accordance with European Law, government licenses and other state-recognised certifications, which allow security functions on ocean-going vessels and are issued by another member state of the European
Union or a contracting state to the Agreement on the European Economic Area, shall be accorded equal treatment with licenses issued pursuant to $§ 31$ (1) GewO. ${ }^{149}$ Other state's licenses may be accorded equal treatment pursuant to $\S 15(2)$ Licensing Ordinance. The prerequisite for the recognition of any such license is, however, that the 'requirements for such foreign licenses or certifications are materially equivalent to the requirements' under the Licensing Ordinance. ${ }^{150}$ A company carrying such other license needs to apply for equal treatment. If this request is granted - by way of an 'official notification' ${ }^{151}$ from the BAFA - this permission has a term of two years. ${ }^{152} \S 15$ of the Licensing Ordinance deems the notification, reporting and submission obligations of a company applicable in such a case, ${ }^{153}$ which may mean that a company will have reporting obligations vis-à-vis two states.

\subsection{State Oversight and Control}

A critical aspect of any regulation is state oversight and enforcement. This is especially true for rules concerning maritime affairs, since the subject of legal obligations is regularly far from the national authorities' reach. ${ }^{154}$ To achieve meaningful control and oversight, the new regulation first limits the license's duration to two years and thus mandates a regularly repeating licensing procedure. ${ }^{155}$ Furthermore, it addresses the issue within the parameters of its corporate approach in that it acknowledges that there is a need for the authorities to obtain knowledge of any incidents in order to assess whether there was wrongdoing and, if necessary, sanction of misconduct.

To reach this goal, the regulatory framework introduces numerous reporting obligations:

\subsubsection{Reporting Obligations of the Security Company}

The security company is obliged to report every deployment of armed guards to the BAFA. ${ }^{156}$ Furthermore, it needs to report on every incident which led to shots being fired, ${ }^{157}$ any case of loss of weapons and/or ammunition $^{158}$ and changes in the internal organisation of the company. ${ }^{159} \S 14$ of the Licensing Ordinance also regulates, however, that the person liable to provide information may refuse to answer questions, if this would subject the particular person or relatives to crimi-

145. See Salomon and tho Pesch, above n. 25, at 764; with further details in Oehmke, above n. 25, at 461.

146. See $\S 57$ WaffG.

147. Oehmke, above n. 25 , at $457-8$ with further reference and a discussion on the possibility of the German Federal Criminal Police Office to issue exemptions pursuant to § 40(4) WaffG

148. Salomon and tho Pesch, above n. 25, at 765; the legislation in Belgium seems to allow automatic weapons; see Jessen, above n. 66 , at 132 ; however, it only does so on a case-by-case basis; see L. McMahon, 'Belgian Law Permitting Devastating Ammunition Reignites Row Over Appropriate Use of Force', Lloyd's List, 27 February 2013. 
nal proceedings or proceedings under the Administrative Offenses Act. ${ }^{160}$

Noncompliance with these duties is an administrative offence, which may result in a fine of up to 5,000 euros. $^{161}$

\subsubsection{Reporting Obligations of the Ship Omner or Ship Operator}

The master of the vessel in question is also obliged to report incidents. Insofar, the obligations are administered by the Federal Maritime and Hydrographic Agency. As stated previously, ship owners using armed security guards are obliged to apply for an annex to the mandatory ship security plan. This annex is approved subject to the condition that the ship owner adheres to and will ensure that others adhere to the reporting and record-keeping obligations. ${ }^{162}$ Concerning their reach and structure, these duties lean on the IMO's 'Revised Interim Guidance to Shipowners, Ship Operators and Shipmasters on the Use of Privately Contracted Armed Security Personnel on Board Ships in the High Risk Area', which suggests that the 'master should maintain a $\log$ of every circumstance in which firearms are discharged, whether accidental or deliberate' to fully document such events in sufficient detail. ${ }^{163}$ The report should include time and location of the incident, details of events leading up to the incident, written statements by all witnesses and those involved from the ship's crew and security team in the incident, the identity and details of personnel involved in the incident, details of the incident, injuries and/or material damage sustained during the incident, and identify lessons learned from the incident and, where applicable, recommended procedures to prevent a recurrence of the incident. ${ }^{164}$

Thus, in the process of obtaining approval for the ship security plan, the ship owner or operator has to declare that the reporting modalities pursuant to the IMO Guidelines will be adhered to, that is, that they will oblige the master to report to them any such incidents. According to the German Ordinance on Shipboard Security Measures, the company security officer of the ship owner or operator will then have reporting obligations towards the state authorities. First, the company has to report the use of private armed guards 24 hours before entry into a risk area. ${ }^{165}$ The company furthermore has to keep the records of reports from the masters for a period of two years starting at the end of the calen-

160. § 14(3a) Licensing Ordinance; see Salomon and tho Pesch, above n. 22, at 766 .

161. § 144(2), no. 1, GewO and § 16 Licensing Ordinance.

162. $\S 7(2 a)$, sentence 2 , German Ordinance on Shipboard Security Measures (See- Eigensicherungsverordnung).

163. IMO, 'Revised Interim Guidance to Shipowners, Ship Operators and Shipmasters on the Use of Privately Contracted Armed Security Personnel on Board Ships in the High Risk Area', para. 5.16.

164. IMO, 'Revised Interim Guidance to Shipowners, Ship Operators and Shipmasters on the Use of Privately Contracted Armed Security Personnel on Board Ships in the High Risk Area', para. 5.17.

165. $\S 7(2 a)$, sentence 2 , no. 1 , German Ordinance on Shipboard Security Measures. dar year. ${ }^{166}$ It also has to hand them over to the BAFA, the $\mathrm{BSH}$ and the Federal Police in case of an incident where shots were fired or otherwise hand them over after being asked to do so by these authorities. ${ }^{167}$ Noncompliance with those obligations again is an administrative offence punishable with fines up to 5,000 euros. ${ }^{168}$

\subsubsection{Assessment}

Those parallel reporting obligations are meant to offer two different perspectives of an incident and enable the authorities to ascertain the veracity and comprehensiveness of reports. ${ }^{169}$ The authorities themselves characterise these instruments as having an outstanding importance to improve the otherwise lacking mechanisms of control and state oversight. ${ }^{170}$

This assessment is likely exaggerated. State oversight remains a very problematic topic. While the German regulation does attempt to safeguard that the German authorities will be made aware of incidents, it is all too easy to imagine circumstances in which the interests of the security team, the master of the vessel and the shipping company converge in the sense that they have a shared interest to keep German authorities ignorant. A case in point is the Enrica Lexie. This case featured Italian soldiers trying to defend the vessel they were stationed on with armed force, resulting in the death of two fishermen under unclear circumstances. While the case now centres on questions of state immunity, ${ }^{171}$ with the Indian authorities trying to prosecute the Italian soldiers, the case does offer a good example for private armed guards as well. Fishermen often follow large vessels, because they attract fish to the water surface. Private guards' wrongly assessing such a situation may treat them as a threat. If armed force were used in such a case, the reporting obligations of the German regulatory framework would be put to a hard test.

Depending on his or her involvement in an incident, the master of the vessel, being the person ultimately in charge, may have a significant interest not to report the case. After all, any step of publicising it could lead to local authorities of coastal or port states obtaining knowledge as well, putting the master at risk of criminal prosecution. The same applies for the armed guards.

166. $\S 7(2 a)$, sentence 2 , no. 2 , German Ordinance on Shipboard Security Measures.

167. $\S 7(2 a)$, sentence 2 , no. 3, German Ordinance on Shipboard Security Measures.

168. § 12(1), no. 6, German Ordinance on Shipboard Security Measures; Allgemeine Verwaltungsvorschrift für die Erteilung von Buß - und Verwarnungsgeldern für Zuwiderhandlungen gegen strom - und schifffahrtspolizeiliche Vorschriften des Bundes auf Binnen - und Seeschifffahrtsstraßen sowie in der ausschließlichen Wirtschaftszone und auf der Hohen See (Buß - und Verwarnungsgeldkatalog Binnen - und Seeschifffahrtsstraßen - BVKatBin-See), 2015, paras. 37.104100-37.104320 (at 334); Oehmke (above n. 25, at 469) sees a maximum fine of up to 50,000 euros on the basis of $\S 15(1)$, no. 2 Seeaufgabengesetz (Federal Maritime Responsibilities Act), she, however, neglects the above-mentioned administrative regulation limiting administrative fines in these cases.

169. BT-Drs. $18 / 5456$ of 1 July 2015 , above n. 111 , at 12

170. BT-Drs. $18 / 5456$ of 1 July 2015 , above $n .115$, at 12

171. See e.g. Jessen, above n. 66 , at 128 et seq. 
They may even rely on their right not to report pursuant to $\S 14(3 \mathrm{a})$ Licensing Ordinance and the nemo tenetur maxim, that is, the right against self-incrimination. It has also been alluded to the fact that colleagues, that is, other team members of a vessel protection team, who may or may not have been involved in misconduct, may have a tendency to be loyal to their colleagues and as such may not alert the authorities or the company. ${ }^{172}$

The same calculation would apply if the reports actually reach a shipping or security company, especially since a shipping company will regularly want to avoid lengthy police operations on their vessel which may expose them to significant damage claims of their customers, ${ }^{173}$ and a security company will certainly not want to risk publicising an incident. Furthermore, a violation of a reporting obligation is punishable only by a fine of up to 5,000 euros, which will regularly mean violating the reporting obligation and taking the risk of having to pay a fine will be more attractive than risking that an incident is publicised. ${ }^{174}$ Of course, a security company risks their license with an intentional violation of a reporting obligation; however, the withdrawal of the license presupposes that the state authorities obtain knowledge of an incident, which will rarely be the case. ${ }^{175}$ As such, it is conceivable that the German authorities would never receive the information of an Enrica Lexie-like scenario, at least, if the crew and the security team remain physically unscathed. Most likely, they would simply receive a report of ammunition having been lost.

While it is acknowledged that such a scenario is never completely avoidable in a maritime setting, it has been submitted during the legislative process that more can be done to enable state authorities to investigate critical incidents. This remains the case. Mandating the armed guards to wear body or helmet cameras was one suggestion. ${ }^{176}$ While armed guards after a critical incident could report their cameras as lost, a report of lost ammunition and lost body cameras would raise louder alarms and would be a reason to possibly initiate criminal investigations. Another suggestion was to enable the crew of a vessel to anonymously report such incidents to the flag state authorities. ${ }^{177}$ Such reporting mechanisms would not need to be invented but could follow the anonymous reporting mechanism already put into place by the Maritime Labour Convention and would simply need to transfer the 'protection of whistle-blowers' idea of the ISO/PAS 28007:2012 standards in no. $5.9 \mathrm{f}$ to the

172. Oehmke, above n. 25 , at $468-9$.

173. Oehmke, above n. 25, at 470 .

174. See Salomon and tho Pesch, above n. 25, at 767; Oehmke, above n. 25 , at 469 .

175. See Salomon and tho Pesch, above n. 25, at 767; Oehmke, above n. 25 , at 469 .

176. T.R. Salomon and S. tho Pesch, 'Zertifizierung bewaffneter Sicherheitskräfte auf deutschen Handelsschiffen und Staatshaftung', NordÖR 65 at 70 (2012); Salomon and tho Pesch, above n. 25, at 767.

177. Salomon and tho Pesch, above n. 176, at 70; T.R. Salomon and S. tho Pesch, 'License to kill? - Staatshaftung und die Zertifizierung von maritimen Sicherheitsdienstleistern', ZRP 1, at 4 (2012). crew of a vessel. ${ }^{178}$ These suggestions would not make state oversight perfect, but they would surely raise the probability that an incident is reported to the state authorities. However, they were not implemented to this date. Thus, until today, the only possibility to obtain knowledge of an incident and thus be able to investigate is to hope that the companies involved and the private guards as well as the masters of the vessels will adhere to their reporting obligations.

Apart from reporting and record-keeping obligations, BAFA continues to have the rights pursuant to $\S 29$ GewO, namely, to mandate the company to disclose information on certain aspects. Theoretically, the BAFA also has the right to enter the premises of businesses during business hours to inspect the business records. ${ }^{179}$ The right to enter the premises is limited, at least vis-àvis foreign companies, since the BAFA cannot exercise its rights under national law in another sovereign country without its permission. The right to request information, however, is still a viable option. Denying such a right without a sufficient legal reason is - again only seen as an administrative offence, this time pursuant to $\S 146(2)$ no. 4 GewO and thus punishable with a fine of up to 2,500 euros. However, if a security company denies a request for information, the BAFA would likely have sufficient grounds to revoke the license of a company. ${ }^{180}$

\section{Concluding Remarks}

Overall, the new regulation deserves praise in that it intends to raise the quality standards of such a global, dynamic and risk-prone industry. The positive aspects include the close connection to the internationally accepted standards of the IMO, ISO as well as the BMP, which limit the likelihood that the German standards contribute to a fragmented landscape of different national standards. The detailed regulatory framework in the ordinances ensures the clarity of standards. The minimum personnel requirement of four security guards significantly contributes to higher standards, as the tendency to cut costs by reducing the number of guards - especially vital today, since the number of attacks have dropped - is counteracted. However, state oversight and government control remain a significant problem since high material standards only have value when compliance is safeguarded.

178. Salomon and tho Pesch, above n. 25, at 767; in the same direction, Oehmke, above n. 25, at 471

179. § 29 GewO.

180. See e.g. Meßerschmidt, in Pielow (ed.), Beck-OK GewO, § 29, para. 27, with reference to a judgment of the Federal Administrative Court, 28 July 1978, 1 C 43/75, which did not feature a case of a denial of an information request, but a restaurant owner denying cooperation with the police to combat the trade of controlled substances in his business. He was held to be unreliable pursuant to the GewO, because of his denial to cooperate. A case of a denied information request may also call into question the reliability of the management personnel of a maritime security company. 
It is hard to say how the German license scheme would have fared, had the pirate attacks remained at the high rate of 2010-2011. Today, German ship owners still to a large extent sail the high-risk areas under foreign flags. Although this has been the case all along, it still is noteworthy that the regulatory overhaul did not result in a reorientation of the ship owners towards the German flag. The number of security companies that are current BAFA license holders is at eight, ${ }^{181}$ four of which are German companies of which most are not exactly household names in the field of maritime security providers. In January 2014, seven companies were listed as carrying licenses. ${ }^{182}$ Currently, many of the German companies that saw a chance of getting into the market in 2011-2012 seem to have given up on offering vessel protection services, since bigger foreign companies seemingly had too much of a head start in the sector to allow smaller German companies to secure a largeenough market share.

There were a number of reasons why maritime security companies did not apply for a BAFA license more frequently - and they are not necessarily found in the reformed GewO and the WaffG. Practitioners reported early on that while obtaining a license was a complex procedure, obtaining an export license was much more cumbersome and time-consuming. It was not the prime focus of the ministries involved in conceptualising the new regulatory framework that transporting weapons out of Germany for use on ocean-going vessels in international waters is a (temporary) export in the legal sense. Thus, it is subject to additional licensing pursuant to $\S 8$ of the Foreign Trade and Payments Regulation and, if applicable, under Article 4(1) of Regulation (EU) Number 258/2012. ${ }^{183}$ Long waiting periods for security companies were the consequence of this and while foreign companies could build their businesses and operate on non-German-flagged vessels, German security companies were prohibited from working in the field, which resulted in an even greater head start of foreign companies. The BAFA now offers a collective license procedure for repeated temporary exports for companies licensed pursuant to $\S 31 \mathrm{GewO}$, which alleviates some of the delay but results in yet other demands on the internal organisation of the company. ${ }^{184}$ These birth defects of the reformed regulatory framework not

181. The companies are published at http://www.bafa.de/EN/Foreign Trade/Maritime_Security/maritime_security_node.html (last visited 11 May 2018)

182. König and Salomon (2014), above n. 26, at 243.

183. See the BAFA webpage under 'Application Procedure' - 'License under Export Control Law', available at: http://www.bafa.de/EN/ Foreign_Trade/Maritime_Security/maritime_security_node.html; for an extensive analysis of the export control regime, see Oehmke, above $n$. 25 , at 473 et seq.

184. According to the BAFA, the collective license procedure 'permit exports and transfers of goods subject to licensing to different countries and different consignees. The application for such a collective licence procedure licence requires in particular a well-functioning internal export control system (ICP).... In fact, private security services have to install their own ICP in order to manage and comply with the collective licence procedure licences granted.' Available at: http://www.bafa.de/EN/ Foreign_Trade/Maritime_Security/maritime_security_node.html. only hindered German companies but also likely affected how the BAFA license regime was seen in the industry.

Although the presence of only a few companies on the BAFA-list of licensed companies speaks for a very insignificant impact of the German regulations on the industry at large, the regulation seems to have had an impact, nevertheless. In a market where the projection of reliability may mean a significant edge over competitors, it was predicted early on that even though the BAFA license may not be used much in practice, big companies may opt to obtain it as a seal of approval to signal highquality standards. ${ }^{185}$ This came to pass as evidenced by early reactions of security companies hailing the new regulation as an important step to quality assurance in the market. ${ }^{186} \mathrm{Up}$ until today, large international maritime security providers are licensed by the BAFA, meaning they changed their internal business organisation to comply with the German regulation, a factor that may also determine their conduct, if they protect vessels under foreign flags.

Contributions focussing on maritime security providers always end on a similar note. There are many reasons why one may justifiably be uncomfortable with the practice of maritime armed guards acting far away from state oversight in a line of business that will regularly mean that the lives of (presumed) attackers are taken or grievous bodily harm is caused. However, they have proven to be an effective component of the necessary defence of trade vessels against pirate attacks. Because of that, this business model will likely be here to stay. Accordingly, regulating this industry to meet the justified criticism, to counteract possible misconduct and to put state authorities in the know must remain a top priority. However, a more global approach to the topic would be necessary to hinder the possibility of the ship owners to opt out of national legislation by changing their vessels' flags. This is hardly going to come easy since popular flag states will likely be reluctant to introduce restrictive legislation.
185. Salomon and tho Pesch, above n. 25, at 769.

186. 'USA: AdvanFort Praises New Accreditation Criteria for Private Maritime Security Companies', World Maritime News, 9 September 2013, available at: http://bit.ly/2CezQSP. 